\title{
Planomicrobium flavidum sp. nov., isolated from a marine solar saltern, and transfer of Planococcus stackebrandtii Mayilraj et al. 2005 to the genus Planomicrobium as Planomicrobium stackebrandtii comb. nov.
}

\author{
Yong-Taek Jung, ${ }^{1,2}$ So-Jung Kang, ${ }^{1}$ Tae-Kwang Oh, ${ }^{1}$ Jung-Hoon Yoon ${ }^{1}$ \\ and Bong-Hee $\mathrm{Kim}^{2}$ \\ ${ }^{1}$ Korea Research Institute of Bioscience and Biotechnology (KRIBB), PO Box 115, Yusong, Taejon, \\ Republic of Korea \\ ${ }^{2}$ College of Pharmacy, Chungnam National University, Taejon 305-764, Republic of Korea
}

Correspondence Jung-Hoon Yoon jhyoon@kribb.re.kr Bong-Hee Kim bhkimnh@cnu.ac.kr
The genus Planomicrobium was proposed by Yoon et al. (2001) to accommodate a novel species, Planomicrobium koreense, and the reclassification of Planococcus okeanokoites (Nakagawa et al., 1996) and Planococcus momeekinii (Junge et al., 1998) as Planomicrobium okeanokoites and Planomicrobium momeekinii, respectively. Subsequently, Planococcus alkanoclasticus (Engelhardt et al., 2001) and Planococcus psychrophilus (Reddy et al., 2002) were transferred to the genus Planomicrobium as Planomicrobium alkanoclasticum and Planomicrobium psychrophilum, respectively, and two other Planomicrobium species, Planomicrobium chinense (Dai et al., 2005) and Planomicrobium glaciei (Zhang et al., 2009), were described. Members of the genus Planomicrobium have

The GenBank/EMBL/DDBJ accession number for the 16S rRNA gene sequence of strain ISL $-41^{\top}$ is FJ265708. been isolated from fermented seafood, marine mud, Antarctic samples, intertidal sediments and glacier (Nakagawa et al., 1996; Junge et al., 1998; Engelhardt et al., 2001; Yoon et al., 2001; Reddy et al., 2002; Dai et al., 2005; Zhang et al., 2009). In this study, we report the taxonomic characterization of a Planomicrobium-like bacterial strain, ISL- $41^{\mathrm{T}}$, which was isolated from a marine solar saltern in Korea.

Strain ISL- $41^{\mathrm{T}}$ was isolated by means of the standard dilution plating technique at $30{ }^{\circ} \mathrm{C}$ on marine agar 2216 (MA; Difco) supplemented with $8 \%(\mathrm{w} / \mathrm{v}) \mathrm{NaCl}$. The type strains of recognized Planomicrobium species and Planococcus stackebrandtii were used as reference strains for DNA-DNA hybridization and phenotypic characterization. Planomicrobium momeekinii $\mathrm{S}_{2} 3 \mathrm{~F}^{\mathrm{T}}$ and Planomicrobium koreense ${\mathrm{JG} 07^{\mathrm{T}}}$ were obtained from 
previous studies (Junge et al., 1998; Yoon et al., 2001). Planomicrobium okeanokoites NBRC $12536^{\mathrm{T}}$ was obtained from the Institute for Fermentation, Osaka. Planomicrobium chinense DSM $17276^{\mathrm{T}}$, Planomicrobium psychrophilum DSM $14507^{\mathrm{T}}$ and Planococcus stackebrandtii DSM $16419^{\mathrm{T}}$ were obtained from the Deutsche Sammlung von Mikroorganismen und Zellkulturen (DSMZ), Braunschweig, Germany. Planomicrobium alkanoclasticum NCIMB $13489^{\mathrm{T}}$ was obtained from the National Collection of Industrial, Marine and Food Bacteria, Aberdeen, UK. The morphological, physiological and biochemical characteristics of strain ISL- $41^{\mathrm{T}}$ were investigated using routine cultivation at $30{ }^{\circ} \mathrm{C}$ on MA. Cell morphology was examined by using light microscopy (Nikon E600) and transmission electron microscopy. Flagellation was determined using a Philips CM-20 transmission electron microscope with cells from exponentially growing cultures. For this purpose, the cells were negatively stained with $1 \%(\mathrm{w} / \mathrm{v})$ phosphotungstic acid and the grids were examined after being air-dried. Growth under anaerobic conditions was determined after incubation in a Forma anaerobic chamber on MA and MA supplemented with potassium nitrate $(0.1 \%, \mathrm{w} / \mathrm{v})$, both of which had been prepared anaerobically under a nitrogen atmosphere. The $\mathrm{pH}$ range for growth was determined in marine broth 2216 (MB; Difco) that was adjusted to various $\mathrm{pH}$ values ( $\mathrm{pH} 4.5-9.5$ at intervals of $0.5 \mathrm{pH}$ units) by the addition of $\mathrm{HCl}$ or $\mathrm{Na}_{2} \mathrm{CO}_{3}$. Growth in the absence of $\mathrm{NaCl}$ was investigated using trypticase soy broth prepared according to the formula of the Difco medium except that $\mathrm{NaCl}$ was excluded from the medium formula. Growth at various $\mathrm{NaCl}$ concentrations $(0.5 \%, \mathrm{w} / \mathrm{v}$, and $1.0-15.0 \%$, $\mathrm{w} / \mathrm{v}$, in $1.0 \%$ increments) was investigated in $\mathrm{MB}$ or trypticase soy broth (Difco). Growth at various temperatures $\left(4,10,20,25,28,30,35,37,40\right.$ and $\left.45^{\circ} \mathrm{C}\right)$ was measured on MA. Catalase and oxidase activities and hydrolysis of casein, starch and Tweens 20, 40, 60 and 80 were determined as described by Cowan \& Steel (1965). Hydrolysis of hypoxanthine, tyrosine and xanthine was tested on MA using the substrate concentrations described by Cowan \& Steel (1965). Hydrolysis of aesculin, gelatin and urea and nitrate reduction were investigated as described previously (Lányi, 1987) with the modification that artificial seawater was used for preparation of media. The artificial seawater contained $\left(1^{-1}\right.$ distilled water): $23.6 \mathrm{~g} \mathrm{NaCl}, 0.64 \mathrm{~g} \mathrm{KCl}, 4.53 \mathrm{~g} \mathrm{MgCl}_{2} .6 \mathrm{H}_{2} \mathrm{O}, 5.94 \mathrm{~g}$ $\mathrm{MgSO}_{4} \cdot 7 \mathrm{H}_{2} \mathrm{O}$ and $1.3 \mathrm{~g} \mathrm{CaCl} 2 \cdot 2 \mathrm{H}_{2} \mathrm{O}$ (Bruns et al., 2001). $\mathrm{H}_{2} \mathrm{~S}$ production was tested as described previously (Bruns et al., 2001). Susceptibility to antibiotics was investigated on MA plates by using antibiotic discs with the following concentrations: polymyxin B (100 U), streptomycin $(50 \mu \mathrm{g})$, penicillin $\mathrm{G}(20 \mathrm{U})$, chloramphenicol $(100 \mu \mathrm{g})$, ampicillin $(10 \mu \mathrm{g})$, cephalothin $(30 \mu \mathrm{g})$, gentamicin $(30 \mu \mathrm{g})$, novobiocin $(5 \mu \mathrm{g})$, tetracycline $(30 \mu \mathrm{g})$, kanamycin $(30 \mu \mathrm{g})$, lincomycin $(15 \mu \mathrm{g})$, oleandomycin $(15 \mu \mathrm{g})$, neomycin $(30 \mu \mathrm{g})$ and carbenicillin $(100 \mu \mathrm{g})$. Acid production from carbohydrates was tested as described by Leifson (1963). Enzyme activities were determined by using the API ZYM system (bioMérieux).
Cell biomass for DNA extraction and for isoprenoid quinone analysis was obtained from cultures grown at $30{ }^{\circ} \mathrm{C}$ in MB. Chromosomal DNA was isolated and purified according to the method described by Yoon et al. (1996), with the exception that RNase T1 was used in combination with RNase A to minimize the contamination of RNA. The 16S rRNA gene was amplified by PCR using two universal primers, 5'-GAGTTTGATCCTGGCTCAG$3^{\prime}$ and $5^{\prime}$-AGAAAGGAGGTGATCCAGCC- ${ }^{\prime}$, as described previously (Yoon et al., 1998). Sequencing of the amplified $16 \mathrm{~S}$ rRNA gene and phylogenetic analysis were performed as described by Yoon et al. (2003). Isoprenoid quinones were analysed as described by Komagata \& Suzuki (1987) using reversed-phase HPLC and a YMC ODS-A $(250 \times 4.6 \mathrm{~mm})$ column. For cellular fatty acid analysis, cell mass of strain ISL- $41^{\mathrm{T}}$ was harvested from MA plates after cultivation for 3 days at $30{ }^{\circ} \mathrm{C}$. The fatty acids were extracted and fatty acid methyl esters were prepared according to the standard protocol of the MIDI/Hewlett Packard Microbial Identification System (Sasser, 1990). The DNA $\mathrm{G}+\mathrm{C}$ content was determined by using the method of Tamaoka \& Komagata (1984) with the modification that DNA was hydrolysed using nuclease P1 (Sigma) and the resultant nucleotides were analysed by reversed-phase HPLC. DNA-DNA hybridization was performed fluorometrically by using the method of Ezaki et al. (1989) with photobiotin-labelled DNA probes and microdilution wells. Hybridization was performed with five replications for each sample. The highest and lowest values obtained in each sample were excluded, and the means of the remaining three values were quoted as DNA-DNA relatedness values.

Morphological, cultural, physiological and biochemical characteristics of strain ISL- $41^{\mathrm{T}}$ are given in the species description or are shown in Table 1. The almost-complete $16 \mathrm{~S}$ rRNA gene sequence of strain ISL- $41^{\mathrm{T}}$ determined in this study comprised $1506 \mathrm{nt}$. In the phylogenetic tree based on the neighbour-joining algorithm, strain ISL- $41^{\mathrm{T}}$ fell within the clade comprising Planomicrobium species and Planococcus stackebrandtii (Fig. 1). The 16S rRNA gene of strain ISL- $41^{\mathrm{T}}$ contained the same signature nucleotides as those defined for the genus Planomicrobium as described by Dai et al. (2005). Strain ISL- $41^{\mathrm{T}}$ exhibited $16 \mathrm{~S}$ rRNA gene sequence similarity values of $97.4-98.6 \%$ to the type strains of Planomicrobium species and Planococcus stackebrandtii, and $96.5-97.9 \%$ to the type strains of other Planococcus species.

The menaquinone profile of strain ISL- $41^{\mathrm{T}}$ was characterized by the predominance of MK-8 (approx. 72\%), followed by MK-7 (approx. 21\%) and MK-6 (approx. $5 \%)$. The fatty acid profile of strain ISL $-41^{\mathrm{T}}$ was comprised of the following (each constituting $>0.5 \%$ of total fatty acids): branched fatty acids anteiso- $\mathrm{C}_{15: 0}(39.0 \%)$, iso$\mathrm{C}_{16: 0}(11.5 \%)$, anteiso- $\mathrm{C}_{17: 0}(11.3 \%)$, iso- $\mathrm{C}_{14: 0}(8.0 \%)$, iso- $\mathrm{C}_{17: 0}(2.8 \%)$, iso- $\mathrm{C}_{17: 1} \omega 10 c(2.8 \%)$, iso- $\mathrm{C}_{15: 0}(1.8 \%)$ and iso- $\mathrm{C}_{18: 0}(1.3 \%)$; unsaturated fatty acids $\mathrm{C}_{16: 1} \omega 7 \mathrm{c}$ alcohol $(11.0 \%)$ and $\mathrm{C}_{16: 1} \omega 11 \mathrm{c}(1.0 \%)$; and summed 
Table 1. Differential phenotypic characteristics of Planomicrobium species and Planococcus stackebrandtii

Taxa: 1, strain ISL-41 ${ }^{\mathrm{T}}$ (Planomicrobium flavidum sp. nov.); 2, Planomicrobium koreense (data from Yoon et al., 2001); 3, Planomicrobium okeanokoites (Nakagawa et al., 1996; Yoon et al., 2001); 4, Planomicrobium mcmeekinii (Junge et al., 1998; Yoon et al., 2001); 5, Planomicrobium chinense (Dai et al., 2005); 6, Planomicrobium psychrophilum (Reddy et al., 2002; this study); 7, Planomicrobium alkanoclasticum (Engelhardt et al., 2001; this study); 8, Planomicrobium glaciei (Zhang et al., 2009); 9, Planococcus stackebrandtii (Mayilraj et al., 2005). +, Positive reaction; -, negative reaction; w, weakly positive reaction; ND, not determined. All species are positive for motility and catalase activity (not determined for Planomicrobium chinense).

\begin{tabular}{|c|c|c|c|c|c|c|c|c|c|}
\hline Characteristic & 1 & 2 & 3 & 4 & 5 & 6 & 7 & 8 & 9 \\
\hline Gram-stain & $\begin{array}{c}\text { Positive to } \\
\text { variable }\end{array}$ & $\begin{array}{c}\text { Positive to } \\
\text { variable }\end{array}$ & $\begin{array}{c}\text { Positive to } \\
\text { variable }\end{array}$ & Positive & Positive & Positive & $\begin{array}{c}\text { Positive or } \\
\text { variable }\end{array}$ & Positive & Positive \\
\hline Colony colour $\dagger$ & Light yellow & $\begin{array}{r}\text { Yellow- } \\
\text { orange }\end{array}$ & $\begin{array}{c}\text { Bright yel- } \\
\text { low-bright } \\
\text { orange }\end{array}$ & Pale orange & $\begin{array}{r}\text { Yellow- } \\
\text { orange }\end{array}$ & Orange & Orange & $\begin{array}{r}\text { Yellow- } \\
\text { orange }\end{array}$ & Orange \\
\hline $\begin{array}{l}\text { Nitrate reduction to } \\
\text { nitrite }\end{array}$ & - & - & - & + & + & - & - & + & - \\
\hline \multicolumn{10}{|l|}{ Growth in: } \\
\hline $7 \% \mathrm{NaCl}$ & + & $\mathrm{W}$ & - & + & + & + & - & + & + \\
\hline $10 \% \mathrm{NaCl}$ & + & - & - & + & + & + & - & + & - \\
\hline \multicolumn{10}{|l|}{ Hydrolysis of: } \\
\hline Tween 80 & + & - & - & - & - & + & $\mathrm{ND}$ & - & $\mathrm{ND}$ \\
\hline \multicolumn{10}{|l|}{$\begin{array}{l}\text { Acid production } \\
\text { from: } \neq\end{array}$} \\
\hline L-Arabinose & - & - & - & - & - & - & - & ND & - \\
\hline Cellobiose & - & + & - & - & - & - & + & $\mathrm{ND}$ & $\mathrm{ND}$ \\
\hline D-Fructose & + & - & + & + & $\mathrm{ND}$ & + & + & $\mathrm{ND}$ & + \\
\hline D-Glucose & - & $\mathrm{W}$ & - & + & + & - & + & $\mathrm{ND}$ & - \\
\hline Lactose & - & + & - & - & - & - & - & $\mathrm{ND}$ & + \\
\hline Maltose & - & + & - & $\mathrm{W}$ & $\mathrm{ND}$ & - & - & $\mathrm{ND}$ & $\mathrm{ND}$ \\
\hline D-Mannose & - & - & - & - & - & - & - & ND & $\mathrm{ND}$ \\
\hline Melibiose & - & + & - & - & - & - & - & $\mathrm{ND}$ & $\mathrm{ND}$ \\
\hline $\begin{array}{l}\text { DNA G +C content } \\
(\mathrm{mol} \%)\end{array}$ & 45.9 & 47 & 46 & 35 & 34.8 & 44.5 & $45.3 \pm 0.4$ & 49 & 40 \\
\hline
\end{tabular}

${ }^{\star} \mathrm{C}$, Cocci; R, rods; SR, short rods.

$\dagger$ Differences may be caused by different cultivation conditions.

\$Data for Planomicrobium psychrophilum and Planomicrobium alkanoclasticum are from this study.

feature 4 (iso- $\mathrm{C}_{17: 1} \mathrm{I}$ and/or anteiso- $\mathrm{C}_{17: 1} \mathrm{~B} ; 8.4 \%$ ). This fatty acid profile was similar to those of Planomicrobium species and Planococcus stackebrandtii, although there were differences in the proportions of some fatty acids, probably because of differences in cultivation conditions and extraction procedures (Engelhardt et al., 2001; Reddy et al., 2002; Mayilraj et al., 2005; Dai et al., 2005). The DNA $\mathrm{G}+\mathrm{C}$ content of strain ISL- $41^{\mathrm{T}}$ was $45.9 \mathrm{~mol} \%$. The results obtained from chemotaxonomic analyses showed the properties that are shared by Planomicrobium species and thereby support the result of the phylogenetic analysis, i.e. that strain ISL- $41^{\mathrm{T}}$ belongs to the genus Planomicrobium. 


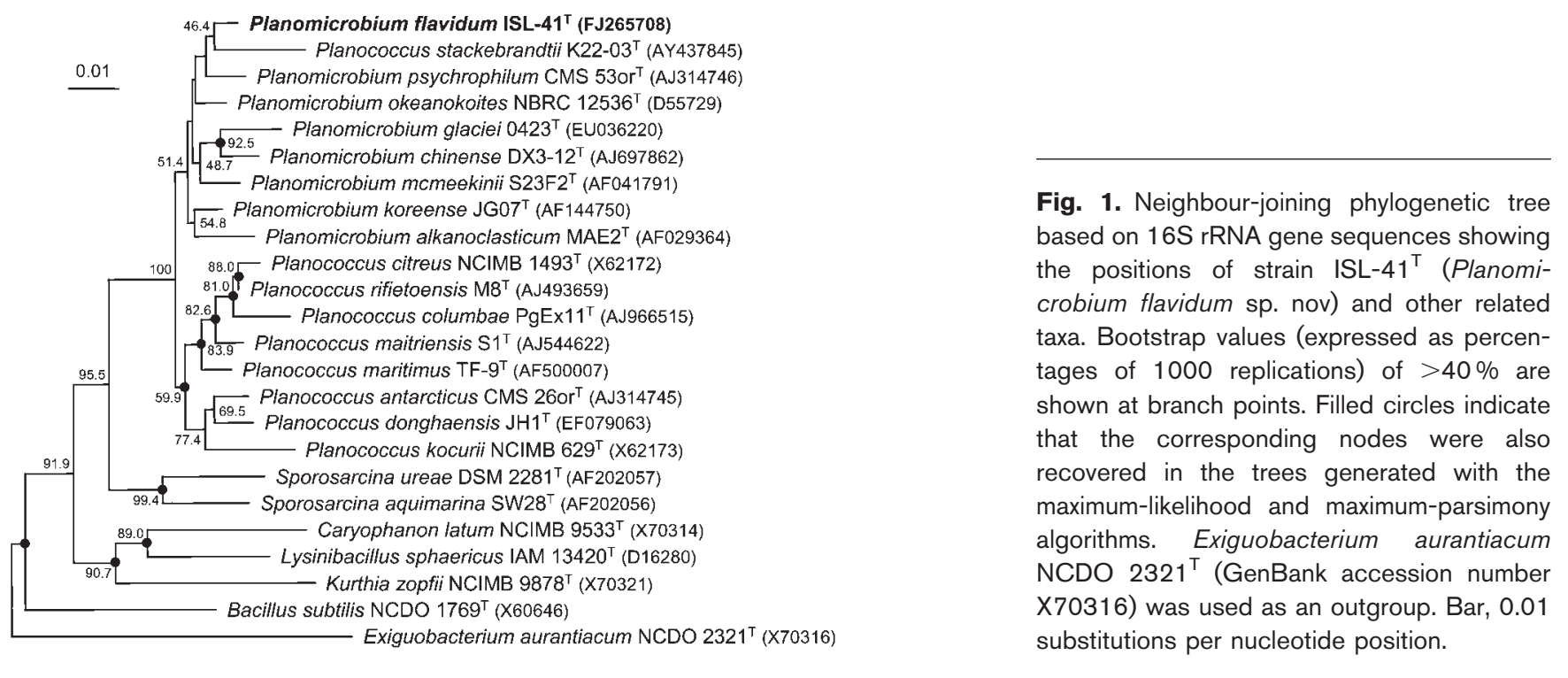

Strain ISL- $41^{\mathrm{T}}$ exhibited mean DNA-DNA relatedness values of $13-25 \%$ to Planomicrobium koreense $\mathrm{JG}^{\mathrm{T}}{ }^{\mathrm{T}}$, Planomicrobium okeanokoites NBRC $12536^{\mathrm{T}}$, Planomicrobium momeekinii $\mathrm{S} 23 \mathrm{~F} 2{ }^{\mathrm{T}}$, Planomicrobium chinense DSM $17276^{\mathrm{T}}$, Planomicrobium psychrophilum DSM $14507^{\mathrm{T}}$, Planomicrobium alkanoclasticum NCIMB $13489^{\mathrm{T}}$ and Planococcus stackebrandtii DSM $16419^{\mathrm{T}}$. Strain ISL- $41^{\mathrm{T}}$ was distinguishable from recognized Planomicrobium species and Planococcus stackebrandtii by differences in several phenotypic characteristics as listed in Table 1. The phylogenetic and genetic distinctiveness and differential phenotypic properties of strain ISL- $41^{\mathrm{T}}$ were sufficient to categorize it as a member of a species that is distinct from the recognized Planomicrobium species and Planococcus stackebrandtii (Wayne et al., 1987; Stackebrandt \& Goebel, 1994). Also, it appears to be appropriate that Planococcus stackebrandtii should be reclassified as a member of the genus Planomicrobium. The phylogenetic trees based on $16 \mathrm{~S}$ rRNA gene sequences showed that Planococcus stackebrandtii $\mathrm{K} 22-03^{\mathrm{T}}$ fell within the cluster comprising Planomicrobium species, not Planococcus species (Fig. 1; Dai et al., 2005; Zhang et al., 2009). In the neighbourjoining phylogenetic tree, the relationship between the cluster comprising Planomicrobium species and Planococcus stackebrandtii $\mathrm{K} 22-03^{\mathrm{T}}$ and the cluster comprising other Planococcus species was maintained by a bootstrap resampling value of $100 \%$ (Fig. 1; Dai et al., 2005; Zhang et al., 2009). The 16S rRNA gene of Planococcus stackebrandtii $\mathrm{K} 22-03^{\mathrm{T}}$ was found to have signature nucleotides at positions at 183 and 190 (Escherichia coli $16 \mathrm{~S}$ rRNA numbering) characteristic of the genus Planomicrobium rather than the genus Planococcus as described by Dai et al. (2005). Accordingly, it is proposed that Planococcus stackebrandtii should be transferred to the genus Planomicrobium as Planomicrobium stackebrandtii comb. nov. In addition, on the basis of the data presented, strain ISL- $41^{\mathrm{T}}$ should be classified as representing a novel species of the genus Planomicrobium, for which the name Planomicrobium flavidum sp. nov. is proposed.

\section{Description of Planomicrobium flavidum sp. nov.}

Planomicrobium flavidum (fla'vi.dum. L. neut. adj. flavidum pale yellow).

Cells are Gram-positive to Gram-variable and cocci or short rods $(0.4-0.8 \times 0.4-1.6 \mu \mathrm{m})$; a few cells are rods $(2.7-$ $3.3 \mu \mathrm{m}$ in length) in young cultures. Motile by means of a single polar flagellum. Colonies on MA are circular, raised to slightly convex, glistening, smooth, light yellow in colour and $1.2-2.0 \mathrm{~mm}$ in diameter after incubation for 3 days at $30{ }^{\circ} \mathrm{C}$. Growth occurs at 4 and $37{ }^{\circ} \mathrm{C}$, but not at $40{ }^{\circ} \mathrm{C}$. Optimal $\mathrm{pH}$ for growth is between 7.0 and 8.0; growth occurs at $\mathrm{pH}$ 6.0, but not at $\mathrm{pH}$ 5.5. Growth occurs in the presence of $13 \%(\mathrm{w} / \mathrm{v}) \mathrm{NaCl}$, but not in the absence of $\mathrm{NaCl}$ or in the presence of more than $14 \%(\mathrm{w} / \mathrm{v}) \mathrm{NaCl}$. Anaerobic growth does not occur on MA and on MA supplemented with nitrate. $\mathrm{H}_{2} \mathrm{~S}$ is not produced. Tweens 20, 40 and 60 are hydrolysed, but hypoxanthine, xanthine and L-tyrosine are not. Acid is not produced from Dgalactose, melezitose, trehalose, myo-inositol and D-sorbitol. Susceptible to ampicillin, carbenicillin, cephalothin, chloramphenicol, gentamicin, kanamycin, lincomycin, neomycin, novobiocin, oleandomycin, penicillin $G$ and streptomycin, but not to polymyxin B or tetracycline. In assays with the API ZYM system, esterase (C4) and esterase lipase (C8) are present, but alkaline phosphatase, lipase (C14), leucine arylamidase, valine arylamidase, cystine arylamidase, trypsin, $\alpha$-chymotrypsin, acid phosphatase, naphthol-AS-BI-phosphohydrolase, $\alpha$-galactosidase, $\beta$ galactosidase, $\beta$-glucuronidase, $\alpha$-glucosidase, $\beta$-glucosidase, $N$-acetyl- $\beta$-glucosaminidase, $\alpha$-mannosidase and $\alpha$ fucosidase are absent. Predominant menaquinones are MK- 8 and MK-7. Major fatty acids ( $>10 \%$ of total fatty acids) are anteiso- $\mathrm{C}_{15: 0}$, iso- $\mathrm{C}_{16: 0}$, anteiso- $\mathrm{C}_{17: 0}$ and 
$\mathrm{C}_{16: 1} \omega 7 c$ alcohol. The DNA $\mathrm{G}+\mathrm{C}$ content of the type strain is $45.9 \mathrm{~mol} \%$ (determined by HPLC). Other phenotypic characteristics are given in Table 1.

The type strain, ISL $-41^{\mathrm{T}}\left(=\right.$ KCTC $\left.13261^{\mathrm{T}}=\mathrm{CCUG} 56756^{\mathrm{T}}\right)$, was isolated from a marine solar saltern of the Yellow Sea, Korea.

\section{Description of Planomicrobium stackebrandtii Mayilraj et al. 2005 comb. nov.}

Planomicrobium stackebrandtii (sta.cke.brand.ti'i. N.L. gen. n. stackebrandtii of Stackebrandt, to honour Erko Stackebrandt, a German microbiologist, for his valuable contributions to microbial taxonomy and molecular systematics).

Basonym: Planococcus stackebrandtii Mayilraj et al. 2005.

The description is the same as that given by Mayilraj et al. (2005). The type strain is strain $\mathrm{K} 22-03^{\mathrm{T}}$ (=MTCC $6226^{\mathrm{T}}=$ DSM $\left.16419^{\mathrm{T}}=\mathrm{JCM} 12481^{\mathrm{T}}\right)$.

\section{Acknowledgements}

This work was supported by the 21C Frontier program of Microbial Genomics and Applications (grant MG05-0401-2-0) from the Ministry of Education, Science and Technology (MEST) of the Republic of Korea.

\section{References}

Bruns, A., Rohde, M. \& Berthe-Corti, L. (2001). Muricauda ruestringensis gen. nov., sp. nov., a facultatively anaerobic, appendaged bacterium from German North Sea intertidal sediment. Int $J$ Syst Evol Microbiol 51, 1997-2006.

Cowan, S. T. \& Steel, K. J. (1965). Manual for the identification of medical bacteria. London: Cambridge University Press.

Dai, X., Wang, Y.-N., Wang, B.-J., Liu, S.-J. \& Zhou, Y.-G. (2005). Planomicrobium chinense sp. nov., isolated from coastal sediment, and transfer of Planococcus psychrophilus and Planococcus alkanoclasticus to Planomicrobium as Planomicrobium psychrophilum comb. nov. and Planomicrobium alkanoclasticum comb. nov. Int J Syst Evol Microbiol 55, 699-702.

Engelhardt, M. A., Daly, K., Swannell, R. P. J. \& Head, I. M. (2001). Isolation and characterization of a novel hydrocarbon-degrading, Gram-positive bacterium, isolated from intertidal sediment, and description of Planococcus alkanoclasticus sp. nov. J Appl Microbiol 90, 237-247.

Ezaki, T., Hashimoto, Y. \& Yabuuchi, E. (1989). Fluorometric deoxyribonucleic acid-deoxyribonucleic acid hybridization in microdilution wells as an alternative to membrane filter hybridization in which radioisotopes are used to determine genetic relatedness among bacterial strains. Int J Syst Bacteriol 39, 224-229.
Junge, K., Gosink, J. J., Hoppe, H.-G. \& Staley, J. T. (1998). Arthrobacter, Brachybacterium and Planococcus isolates identified from Antarctic sea ice brine. Description of Planococcus momeekinii sp. nov. Syst Appl Microbiol 21, 306-314.

Komagata, K. \& Suzuki, K. (1987). Lipids and cell-wall analysis in bacterial systematics. Methods Microbiol 19, 161-203.

Lányi, B. (1987). Classical and rapid identification methods for medically important bacteria. Methods Microbiol 19, 1-67.

Leifson, E. (1963). Determination of carbohydrate metabolism of marine bacteria. J Bacteriol 85, 1183-1184.

Mayilraj, S., Prasad, G. S., Suresh, K., Saini, H. S., Shivaji, S. \& Chakrabarti, T. (2005). Planococcus stackebrandtii sp. nov., isolated from a cold desert of the Himalayas, India. Int J Syst Evol Microbiol 55, 91-94.

Nakagawa, Y., Sakane, T. \& Yokota, A. (1996). Emendation of the genus Planococcus and transfer of Flavobacterium okeanokoites Zobell and Upham 1944 to the genus Planococcus as Planococcus okeanokoites comb. nov. Int J Syst Bacteriol 46, 866-870.

Reddy, G. S. N., Prakash, J. S. S., Vairamani, M., Prabhakar, S., Matsumoto, G. I. \& Shivaji, S. (2002). Planococcus antarcticus and Planococcus psychrophilus spp. nov. isolated from cyanobacterial mat samples collected from ponds in Antarctica. Extremophiles 6, 253-261.

Sasser, M. (1990). Identification of bacteria by gas chromatography of cellular fatty acids, Technical Note no. 1. Newark, DE: MIDI.

Stackebrandt, E. \& Goebel, B. M. (1994). Taxonomic note: a place for DNA-DNA reassociation and $16 \mathrm{~S}$ rRNA sequence analysis in the present species definition in bacteriology. Int J Syst Bacteriol 44, 846849.

Tamaoka, J. \& Komagata, K. (1984). Determination of DNA base composition by reversed-phase high-performance liquid chromatography. FEMS Microbiol Lett 25, 125-128.

Wayne, L. G., Brenner, D. J., Colwell, R. R., Grimont, P. A. D., Kandler, O., Krichevsky, M. I., Moore, L. H., Moore, W. E. C., Murray, R. G. E. \& other authors (1987). International Committee on Systematic Bacteriology. Report of the ad hoc committee on reconciliation of approaches to bacterial systematics. Int J Syst Bacteriol 37, 463-464.

Yoon, J.-H., Kim, H., Kim, S.-B., Kim, H.-J., Kim, W. Y., Lee, S. T., Goodfellow, M. \& Park, Y.-H. (1996). Identification of Saccharomonospora strains by the use of genomic DNA fragments and rRNA gene probes. Int J Syst Bacteriol 46, 502-505.

Yoon, J.-H., Lee, S. T. \& Park, Y.-H. (1998). Inter- and intraspecific phylogenetic analysis of the genus Nocardioides and related taxa based on 16S rRNA gene sequences. Int J Syst Bacteriol 48, 187-194.

Yoon, J.-H., Kang, S.-S., Lee, K.-C., Kho, Y. H., Kang, K. H. \& Park, Y.-H. (2001). Planomicrobium koreense gen. nov., sp. nov., a bacterium isolated from the Korean traditional fermented seafood jeotgal, and transfer of Planococcus okeanokoites (Nakagawa et al. 1996) and Planococcus momeekinii (Junge et al. 1998) to the genus Planomicrobium. Int J Syst Evol Microbiol 51, 1511-1520.

Yoon, J.-H., Kang, K. H. \& Park, Y.-H. (2003). Psychrobacter jeotgali sp. nov., isolated from jeotgal, a traditional Korean fermented seafood. Int J Syst Evol Microbiol 53, 449-454.

Zhang, D.-C., Liu, H.-C., Xin, Y.-H., Yu, Y., Zhou, P.-J. \& Zhou, Y. G. (2009). Planomicrobium glaciei sp. nov., a psychrotolerant bacterium isolated from a glacier. Int J Syst Evol Microbiol 59, 1387-1390. 